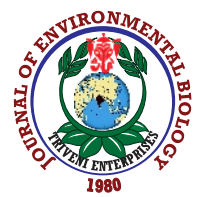

\title{
Characterization of phyllosphere methylotrophic bacteria isolated from the groundnut and their impact on growth, yield and quality of the kernel
}

\author{
R. Krishnamoorthy ${ }^{1,2,}$ R. Anandham ${ }^{1,3 *}$, P. Indiragandhi ${ }^{4}$, R. Vaidyanathan ${ }^{5}$, A. Mothilal ${ }^{4}$, V. Karunakaran ${ }^{4}$, R. Brindavathy ${ }^{5}$, \\ K. Kumutha ${ }^{1}$ and M. Senthilkumar ${ }^{6}$ \\ ${ }^{1}$ Department of Agricultural Microbiology, Agricultural College and Research, Madurai-625104, India \\ ${ }^{2}$ Department of Crop Management, Vanavarayar Institute of Agriculture, Pollachi-642 103, India \\ ${ }^{3}$ Department of Agricultural Microbiology, Tamil Nadu Agricultural University, Coimbatore-641 003, India \\ ${ }^{4}$ Regional Research Station, TNAU, Vriddhachalam-606 001, India \\ ${ }^{5}$ Oilseeds Research Station, TNAU, Tindivanam-612101, India \\ ${ }^{6}$ Department of Crop Management, Agricultural College and Research Institute, TNAU, Eachangkottai-614 902, India \\ *Corresponding Author Email : anandhamranga@gmail.com
}

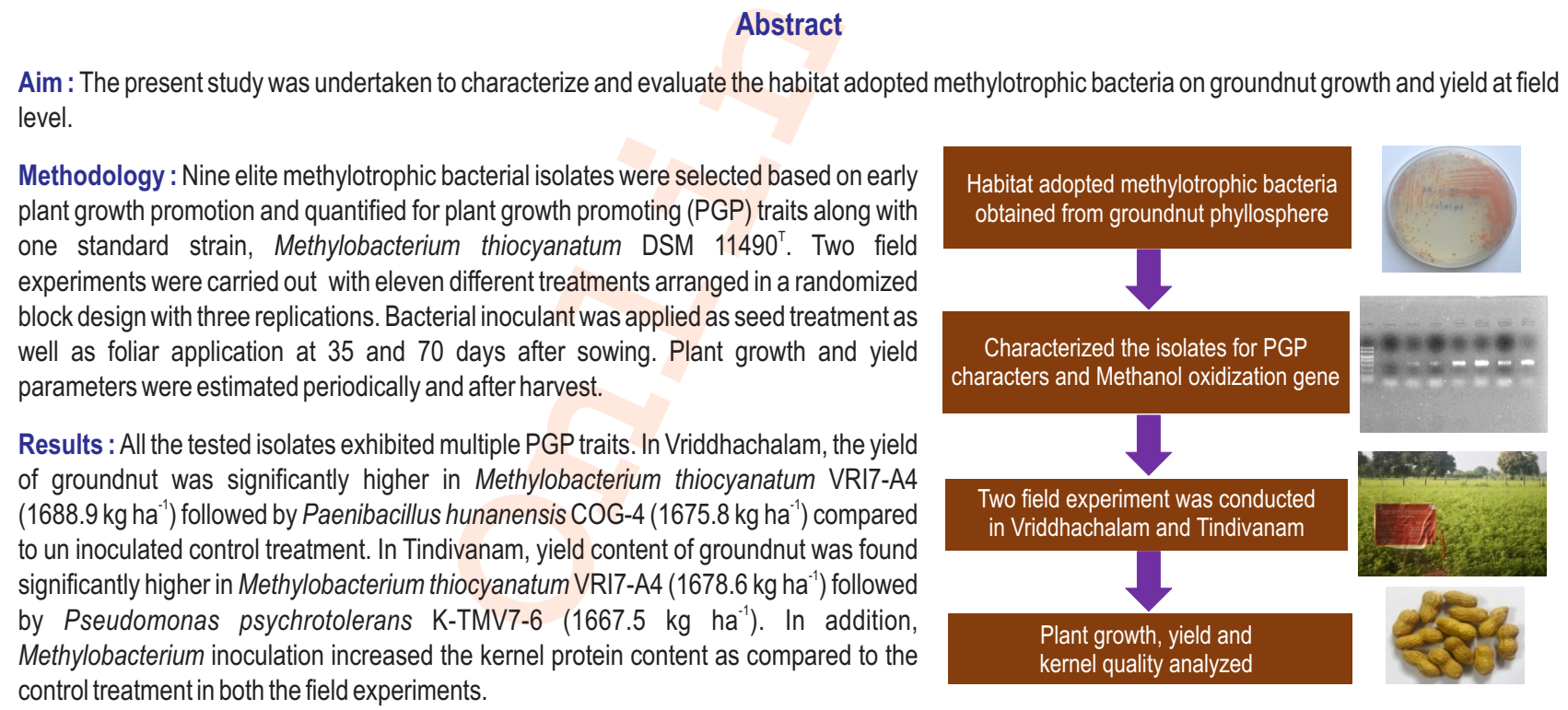

Interpretation : The results showed that Methylobacterium populi TMV7-4, Methylobacterium thiocyanatum VRI7-A4, Pseudomonas psychrotolerans K-TMV7-6 may be used as bio-inoculant for groundnut crop.

Key words: Groundnut, Kernel quality, Methylotrophic bacteria, $m \times a F$ gene

How to cite : Krishnamoorthy, R., R. Anandham, P. Indiragandhi, R. Vaidyanathan, A. Mothilal, V. Karunakaran, R. Brindavathy, K. Kumutha and M. Sentikumar: Characterization of phyllosphere methylotrophic bacteria isolated from the groundnut and their impacton growth, yield and quality of the kernel. J. Environ. Biol., 41, 600-606 (2020). 


\section{Introduction}

Legumes are considered as the third largest family of higher plants, where groundnut (Arachis hypogaea L.) is one of the most vital crops of this family. Groundnut is considered as one of the important crop both economically as well as agriculturally (Krishna et al., 2015). India is one of the leading countries in groundnut production next to China. However, a declining trend in productivity has been observed since 2013 (Economic survey, 2016-2017). In India, area coverage, production and yield of groundnut during 2012-2013 reduced by 0.49 million ha, 2.21 million tons and $415 \mathrm{~kg} \mathrm{ha}^{-1}$, respectively against corresponding period of 2011-2012. In Asian countries, bio-inoculants are included as one of the major component in the integrated soil fertility management programs. Increased use of bio-inoculants results in environmental friendly soil fertility management with the potential of sustainable agriculture development compared to the continuous application of chemical fertilizers alone (Sharma et al., 2013). Use of bio-inoculants for plant nutrition in addition to chemical fertilizer is gaining more importance at field level. Researchers are using microbial inoculants successfully at field level as they have been potentially recognized for stimulating and increasing plant growth and yield (Mukhongo et al., 2017; Bradacova et al., 2019).

Several studies have demonstrated that the combined use of microbial inoculants and reduced / recommend chemical fertilizers can sustain soil fertility and crop yield (Bhardwaj et al., 2014). With the aim of improving plant growth many different types of bio-inoculants have been developed, but most of them are not crop specific. Due to non-crop specific nature of bioinoculants, microorganisms are failed to colonize the plant effectively and their full potential are not achievable (Itelima et al., 2018). To obtain maximum benefits out of bio-inoculants, more attention has to be paid for the selection of efficient crop specific bio-inoculants (Sharma et al., 2009). Habitat adopted methylotrophic bacterial isolates obtained from the phyllosphere of groundnut plants grown in different geographical location of Tamil Nadu were initially tested for early growth promotion in groundnut. Based on the results obtained from the previous study (Krishnamoorthy et al., 2018,) efficient isolates were selected and tested under field level. Keeping in view the above, the objective of this study was to evaluate and select efficient methylotrophic bacterial isolates for enhancing groundnut growth, yield and quality parameters for formulating a groundnut specific bio-inoculant.

\section{Materials and Methods}

Test Microorganisms: Nine methylotrophic bacterial isolates were selected from the isolates obtained from phyllosphere of groundnut leaf samples obtained from different geographical locations of Tamil Nadu in addition one standard Methylotrophic bacterial strain, Methylobacterium thiocyanatum DSM $11490^{\top}$ (kind gift from Prof. Tongmin Sa, Chungbuk National University, South Korea) was also used in this study.
Estimation of plant growth promoting traits: Indole acetic acid production of methylotrophic isolates was quantitatively measured by the method described by Bric et al. (1991). Nitrogen fixing efficiency of the isolates was evaluated by using acetylene reduction assay (ARA). The ARA was calculated and expressed as p moles of ethylene formed per mg of protein (David et al., 1980). ACC deaminase activity was determined by growing the bacterial isolates on nitrogen-free medium amended with $3 \mathrm{mM} \mathrm{ACC}$ as nitrogen source (Penrose and Glick, 2003) and the amount of aketobutyrate produced by the enzymatic hydrolysis of ACC was estimated. The phosphate solublization of methylotrophic isolates were quantitatively determined by inoculation in Pikovskaya's broth supplemented with $0.5 \%$ tricalcium phosphate. The phosphorous content was analyzed by adopting the method of Bray and Kurtz (1945). Exopolysaccharides (EPS) was extracted and quantified by measuring the dry weight (Hebbar et al., 1992) and glucose was measured by phenol-sulphuric acid method (Dubois et al., 1956).

Methanol oxidizing (mxa) gene amplification: The presence of $m x a F$ gene in the bacterial isolates were authenticated by using the gene specific primers. The forward primer mxaF-1003 (5'GCGGCACCAACTGGGGCTGGT-3') and reverse mxaR-1561 (5'-GGGCAGCATGAAGGGCTCCC-3') of 550 bp were used (McDonald and Murrell, 1997). The amplification was carried out in $100 \mu$ laliquots by mixing $50-90 \mathrm{ng}$ template DNA with the PCR buffer $(10 \mathrm{x}) ; 100 \mu \mathrm{M}$ (each) dATP, dCTP, dTTP and dGTP; primers (100 ng each) and $1.0 \mathrm{U}$ Taq polymerase. PCR amplification was performed in a thermocycler using following conditions: initial denaturation at $94^{\circ} \mathrm{C}$ for $5 \mathrm{~min}, 35$ cycles consisting of $95^{\circ} \mathrm{C}$ for $1 \mathrm{~min}$ (denaturation), $52^{\circ} \mathrm{C}$ for $1 \mathrm{~min}$ (annealing), $72^{\circ} \mathrm{C}$ for $1 \mathrm{~min}$ (primer extension) and final extension $72^{\circ} \mathrm{C}$ for 5 min (Meena et al., 2012). PCR products were separated by electrophoresis on $1.5 \%$ agarose gel stained with

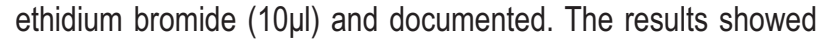
the presences of mxaF gene in all the tested methylotrophic bacterial isolates.

Formulation of liquid bio-inoculant: Microbial formulations were prepared with all the ten methylotrophic bacteria. The cultures were grown in the glycerol peptone liquid medium for 48

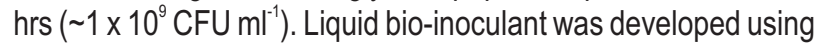
these bacterial cultures with $0.1 \% \mathrm{CMC}$ as sticker and $1 \%$ glycerol as a preservative.

Treatment details and plant biometric parameters: Field level evaluation of ten methylotrophic bacteria were performed in two different locations in Tamil Nadu. One is in Oil Seed Research Station, Tamil Nadu Agricultural University (TNAU) Tindivanam and another one is in Regional Research Station, Vriddhachalam, TNAU, Tamil Nadu, India. All the ten methylotrophic bacterial liquid bio-inoculant formulation were used for seed treatment. Totally 11 treatments (T1 - Acinetobacter baumannii K-TMV7-7; T2 - Pantoea stewartii subsp. indologenes N-CO6-5; T3 Pantoea dispersa ICGV-2; T4 - Methylobacterium populi TMV7 4; T5 - Methylobacterium thiocyanatum VRI7-A4; T6 Methylobacterium radiotolerans VRI8-A4; T7 - Pseudomonas 
psychrotolerans K -TMV7-6; T8 - Paenibacillus hunanensis COG-4; T9 - Rhizobium pusense TMV2-6; T10 Methylobacterium thiocyanatum DSM11490T; T11-Control) with three replications arranged in a randomized block deign.

In Vriddhachalam, the plot size was $3 \times 4 \mathrm{M}$, while in Tindivanam the plot size was 4 x 5 M. In Oil Seed Research Station, Tindivanam Western 44 variety and in Regional Research Station, Vriddhachalam VRI 8 varieties were used. Methylotrophic bacteria were used in seed treatment (1\%) during sowing and foliar application (@10 $\mathrm{ml} \mathrm{I}^{-1}$ ) at 35 and 70 days after sowing. Continuous monitoring was made and followed blanket recommendation of fertilizers $\left(25,50,75\right.$ and $60 \mathrm{~kg} \mathrm{ha}^{-1}$ of N, P, K and Sulphur, respectively). Plants were harvested at their physiological maturity. Growth and yield parameters were tested after harvesting. The crude protein content was evaluated by digestion of the sample using Kjeldahl's method (Devani et al., 1989) and oil content of the kernel was estimated by Soxhlet extraction method (Maranz et al., 2003).

Statistical analyses: The data were subjected to analysis of variance (ANOVA), and the significant of differences between the means was determined by Duncan's Multiple Range Test (DMRT) at $p<0.05$. All of the data were analyzed using IBM SPSS Statistics 20.

\section{Results and Discussion}

Many of the plant beneficial bacteria are plant species specific and establish close association with the similar plant species. In a previous study, crop specific methylotrophic bacteria were isolated and screened for groundnut early plant growth promotion (Krishnamoorthy et al., 2018). In continuation with previous study (Krishnamoorthy et al., 2018), , nine efficient isolates were used at field level (in two locations) to develop a crop specific bio-inoculant along with one standard methylotrophic strain. All the tested ten isolates produced various amount of IAA and EPS. Higher IAA and EPS were produced by Pantoea stewartii subsp. indologenes N-CO6-5 $\left(6.6 \mu \mathrm{g} \mathrm{ml}^{-1}\right)$ and Pantoea dispersa ICGV-2 $\left(4.5 \mu \mathrm{g} \mathrm{ml}^{-1}\right)$, respectively (Table 1).

IAA production by the phyllosphere bacteria were previously reported (Akter et al., 2016). Higher ARA activity was found in the Pseudomonas psychrotolerans K-TMV7-6 (2546 $\mathrm{pmol}$ of ethylene/mg protein/h). Rhizobium pusense TMV 2-6 showed higher ACC deaminase activity and higher amount of $P$ released by Pantoea dispersa ICGV-2 and Paenibacillus hunanensis COG-4 (2.62 g/l) from insoluble P source. Similarly, $P$ solubilization nature of Pantoea and Paenibacillus was reported (Hernandez et al., 2018). Nitrogen is one of the major nutrients required by the plants for their proper cell functions. Nitrogen fixing ability of methylotrophic isolates were previously reported from Jatropha curcas (Madhaiyan et al., 2015). In this study, 56 percent of the isolates exhibited nitrogen fixing ability. ACC deaminase-containing methylotrophic bacteria could reduce a significant portion of the plant damage by breaking down the ethylene precursor in to ammonia and a-ketobutyrate. Bacteria which possess ACC deaminase was well proven to mitigate stress in various plants (Win et al., 2018; Saikia et al., 2018).

In this study, 78 percent of the isolates were found to produce ACC deaminase which might help in mitigating stress in plants. Phosphorus is one of the major essential macronutrients required for plant growth and development, but in soil most of the phosphorus are converted to insoluble form by reacting with other soil ions. Jayashree et al. (2011) reported the production of organic acids and enzymes for solubilization of insoluble phosphorus by methylotrophic isolates. Qualitative plant growth promoting traits of total 80 methylotrophic bacterial isolates data were given in the previous report (Krishnamoorthy et al., 2018). However, it is very hard to select efficient isolate with multiple plant growth promoting traits only with the qualitative data. Hence, quantitative estimation of plant growth promoting traits were performed in this study. In addition, to confirm the methanol

Table 1: Quantitative estimation of multiple PGP traits of selected methylotrophic bacterial isolates

\begin{tabular}{|c|c|c|c|c|c|}
\hline Isolate & $\begin{array}{l}\text { IAA production } \\
\left(\mu \mathrm{g} \mathrm{ml}^{-1}\right)\end{array}$ & $\begin{array}{l}\text { ARA activity } \\
\left(\text { pmol } \mathrm{mg}^{-1}\right. \\
\left.\text { protein } \mathrm{hr}^{-1}\right)\end{array}$ & $\begin{array}{l}\text { ACC deaminase } \\
\text { (nmolug/ } \\
\left.\text { protein } \mathrm{hr}^{-1}\right)\end{array}$ & $\begin{array}{l}\text { P solubilization } \\
\left(\mathrm{g}^{-1}\right)\end{array}$ & $\begin{array}{l}\text { EPS production } \\
\left(\mu \mathrm{gl}^{-1}\right)\end{array}$ \\
\hline Acinetobacter baumannii K-TMV7-7 & $3.1 \pm 0.4$ & ND & ND & $2.59 \pm 0.36$ & $3.3 \pm 0.25$ \\
\hline Pantoea stewartii subsp. indologenes N-CO6-5 & $6.6 \pm 0.9$ & ND & $0.13 \pm 0.005$ & $2.41 \pm 0.33$ & $3.5 \pm 0.04$ \\
\hline Pantoea dispersa ICGV-2 & $5.1 \pm 0.7$ & $508 \pm 175$ & $0.90 \pm 0.06$ & $2.62 \pm 0.36$ & $4.5 \pm 0.36$ \\
\hline Methylobacterium populi TMV7-4 & $4.1 \pm 0.6$ & ND & $2.40 \pm 0.09$ & ND & $3.4 \pm 0.16$ \\
\hline Methylobacterium thiocyanatum VRI7-A4 & $3.3 \pm 0.4$ & $58 \pm 1.9$ & $0.22 \pm 0.007$ & ND & $4.1 \pm 0.04$ \\
\hline Methylobacterium radiotolerans VRI8-A4 & $2.5 \pm 0.3$ & ND & ND & ND & $3.1 \pm 0.01$ \\
\hline Pseudomonas psychrotolerans K-TMV7-6 & $4.9 \pm 0.7$ & $2546 \pm 436$ & $1.39 \pm 0.04$ & $2.44 \pm 0.33$ & $4.2 \pm 0.12$ \\
\hline Paenibacillus hunanensis COG-4 & $4.1 \pm 0.6$ & $193 \pm 58$ & $0.73 \pm 0.08$ & $2.62 \pm 0.36$ & $3.1 \pm 0.01$ \\
\hline Rhizobium pusense TMV 2-6 & $3.6 \pm 0.5$ & $271 \pm 86$ & $3.09 \pm 0.08$ & $0.32 \pm 0.04$ & $4.8 \pm 0.04$ \\
\hline Methylobacterium thiocyanatum DSM11490T & $3.3 \pm 0.5$ & $1816 \pm 314$ & $0.26 \pm 0.04$ & $2.59 \pm 0.35$ & $3.1 \pm 0.01$ \\
\hline
\end{tabular}

Data are mean of five replicates \pm S.E.; IAA - Indole acetic acid; ARA - acetylene reduction assay; ACC deaminase-1-aminocyclopropane-1-carboxylate deaminase; EPS-Exopolysaccharides; ND - not detected 
Table 2: Effect of methylotrophic bacterial isolates on groundnut yield and kernel quality under field condition after 75 days of sowing

\begin{tabular}{|c|c|c|c|c|c|c|}
\hline \multirow[b]{2}{*}{ Treatments } & \multicolumn{4}{|c|}{ Vriddhachalam } & \multicolumn{2}{|l|}{ Tindivanam } \\
\hline & $\begin{array}{l}\text { Pod yield } \\
\left(\mathrm{kg} \mathrm{ha}^{-1}\right)\end{array}$ & $\begin{array}{l}\text { Oil } \\
\text { percentage }\end{array}$ & $\begin{array}{l}\text { Protein } \\
(\%)\end{array}$ & $\begin{array}{l}\text { Pod yield } \\
\left(\mathrm{kg} \mathrm{ha}^{-1}\right)\end{array}$ & $\begin{array}{l}\text { Oil } \\
\text { percentage }\end{array}$ & $\begin{array}{l}\text { Protein } \\
(\%)\end{array}$ \\
\hline T1 - Acinetobacter baumanniiK-TMV7-7 & $1567.5 \pm 14.6^{\mathrm{a}}$ & $49.8 \pm 1.2^{\mathrm{a}}$ & $24.6 \pm 1.0^{c}$ & $1591.7 \pm 15.8^{\mathrm{a}}$ & $47.6 \pm 0.6^{\mathrm{a}}$ & $22.6 \pm 1.2^{\mathrm{a}}$ \\
\hline T2 - Pantoea stewartii subsp. indologenesN-CO6-5 & $1580.0 \pm 16.3^{\mathrm{a}}$ & $49.0 \pm 0.6^{\mathrm{a}}$ & $22.4 \pm 0.8^{\mathrm{a}}$ & $1585.0 \pm 10.1^{\mathrm{a}}$ & $46.5 \pm 0.2^{\mathrm{a}}$ & $23.9 \pm 0.6^{\text {a }}$ \\
\hline T3 - Pantoea dispersa/CGV-2 & $1563.3 \pm 13.1^{\mathrm{a}}$ & $49.2 \pm 1.1^{\mathrm{a}}$ & $26.6 \pm 1.8^{c}$ & $1589.2 \pm 8.8^{\mathrm{a}}$ & $47.2 \pm 1.2^{\mathrm{a}}$ & $25.6 \pm 1.1^{\mathrm{b}}$ \\
\hline T4 - Methylobacterium populiTMV7-4 & $1632.6 \pm 32.9^{b}$ & $50.1 \pm 0.6^{\mathrm{a}}$ & $23.5 \pm 0.9^{\mathrm{ab}}$ & $1643.4 \pm 35.5^{b}$ & $48.5 \pm 2.1^{\mathrm{a}}$ & $25.0 \pm 0.6^{b}$ \\
\hline T5 - Methylobacterium thiocyanatumVRI7-A4 & $1688.9 \pm 16.9^{b}$ & $51.0 \pm 1.6^{\mathrm{a}}$ & $26.0 \pm 1.2^{c}$ & $1678.6 \pm 41.4^{b}$ & $48.0 \pm 1.0^{\mathrm{a}}$ & $26.8 \pm 1.8^{b}$ \\
\hline T6 - Methylobacterium radiotoleransVRI8-A4 & $1581.7 \pm 22.4^{\mathrm{a}}$ & $49.9 \pm 0.5^{\mathrm{a}}$ & $24.0 \pm 0.4^{b}$ & $1605.0 \pm 8.8^{\mathrm{ab}}$ & $47.9 \pm 0.6^{\mathrm{a}}$ & $25.6 \pm 0.9^{b}$ \\
\hline T7 - Pseudomonas psychrotoleransK-TMV7-6 & $1647.2 \pm 26.5^{b}$ & $50.0 \pm 1.8^{\mathrm{a}}$ & $24.2 \pm 0.3^{b}$ & $1667.5 \pm 33.6^{b}$ & $49.3 \pm 0.5^{\mathrm{a}}$ & $24.2 \pm 0.3^{b}$ \\
\hline T8- Paenibacillus hunanensisCOG-4 & $1675.8 \pm 19.3^{b}$ & $49.8 \pm 0.7^{\mathrm{a}}$ & $20.1 \pm 1.1^{\mathrm{a}}$ & $1599.2 \pm 2.2^{\mathrm{a}}$ & $48.0 \pm 0.2^{\mathrm{a}}$ & $22.1 \pm 1.9^{\mathrm{a}}$ \\
\hline T9- Rhizobium pusenseTMV 2-6 & $1529.7 \pm 21.9^{\mathrm{a}}$ & $49.6 \pm 0.6^{\mathrm{a}}$ & $24.4 \pm 0.4^{b}$ & $1588.3 \pm 6.7^{\mathrm{a}}$ & $47.2 \pm 0.6^{\mathrm{a}}$ & $20.4 \pm 0.6^{a}$ \\
\hline T10 - Methylobacterium thiocyanatumDSM11490T & $1574.5 \pm 12.3^{\mathrm{a}}$ & $49.5 \pm 1.8^{\mathrm{a}}$ & $24.8 \pm 1.0^{\mathrm{b}}$ & $1592.5 \pm 11.8^{\mathrm{a}}$ & $47.0 \pm 0.8^{\mathrm{a}}$ & $25.5 \pm 1.5^{b}$ \\
\hline T11 - Control & $1562.3 \pm 6.9^{\mathrm{a}}$ & $49.5 \pm 1.6^{\mathrm{a}}$ & $24.0 \pm 0.8^{b}$ & $1592.5 \pm 5.2^{\mathrm{a}}$ & $47.3 \pm 0.9^{\mathrm{a}}$ & $22.9 \pm 0.9^{\mathrm{a}}$ \\
\hline
\end{tabular}

Data are mean of five replicates $\pm S . E ; p<0.05$ according to DMRT, different letters indicate difference among treatments

utilizing ability of the isolates, presence of methanol dehydrogenase $(\mathrm{MDH})$ gene in the isolates was identified by gene amplification study. The enzyme MDH involved in oxidizing methanol to formaldehyde, the intermediate during the metabolism in methylotrophs. The gene encoding a subunit of MDH is $m x a F$, which is highly conserved functional gene often used for methylotrophic diversity analysis (Lau et al., 2013). The presence of $m \times a F$ gene ( 550bp) in all the ten methylotrophic isolates used in this study is presented in Fig. 1. Similarly the presence of $m x a F$ gene was detected in methylotrophic isolate obtained from wheat (Meena et al., 2012), Anadenanthera colubrine (Alibrandi et al., 2018) and mustard plant (Subhaswaraj et al., 2017).

In Vriddhachalam, significant increase in shoot length was observed in T4 - Methylobacterium populi TMV7-4, T5 Methylobacterium thiocyanatum VRI7-A4, T6 Methylobacterium radiotolerans VRI8-A4 and T7 Pseudomonas psychrotolerans K-TMV7-6 and the nodule number was significantly higher in the plants treated with $\mathrm{T5}-$ Methylobacterium thiocyanatum VRI7-A4 and T7 Pseudomonas psychrotolerans K-TMV7-6 (Fig. 2A). Significantly higher root length and dry weight was observed in T4 Methylobacterium populi TMV7-4 and T7 - Pseudomonas psychrotolerans K-TMV7-6 (Fig. 2B). Plant root biomass might be directly correlated with the amount of nutrition and water uptake from soil. Recently Klikno and Kutschera (2017) illustrated that phytohormones produced by Methylobacterium significantly increases the root biomass. Similarly, in this study the methylotrophic bacteria used was found to produce phytohormone auxin and all the isolates enhanced root biomass at field level. In connection with this role of IAA produced by Methylobacterium extorquens MP1 and Methylobacterium zatmanii MS4 in plant root development was well documented (Pattnaik et al., 2017). Even though the plant colonization was not accessed in this study, the increased plant parameters observed in all inoculation treatments indicated that methylotrophic bacteria had effectively established in association with the groundnut plants, in order to express its growth-promotion activities.

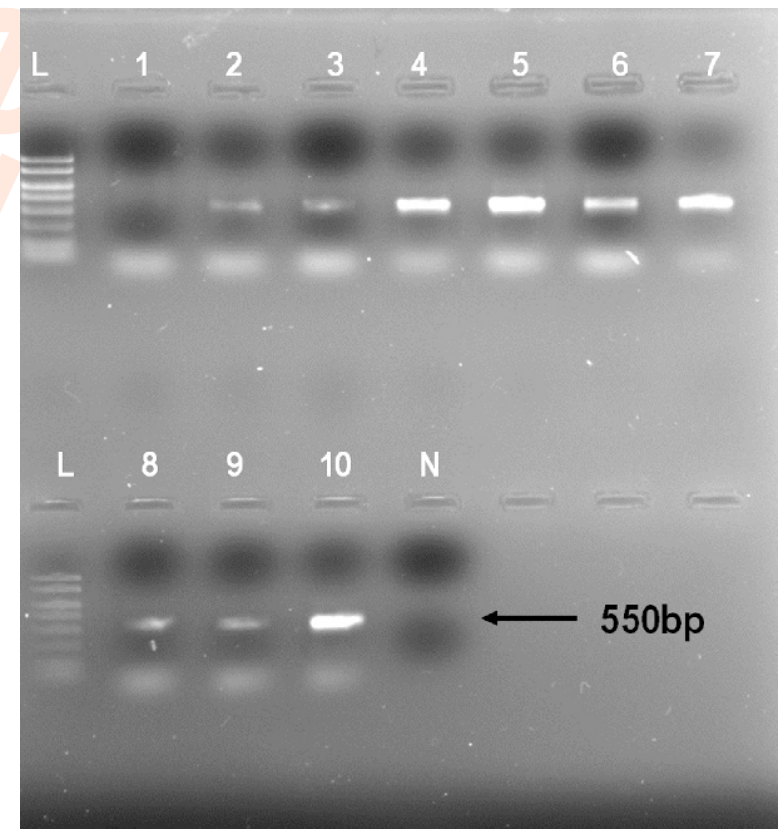

Fig.1: $m \times a F$ gene amplification in methylotrophic bacterial isolates. $L$ 1000bp ladder; N-Negative control; 1-Acinetobacter baumannii KTMV7-7; 2-Pantoea stewartii subsp. indologenes N-CO6-5; 3-Pantoea dispersa ICGV-2; 4-Methylobacterium populi TMV7-4; 5Methylobacterium thiocyanatum VRI7-A4; 6-Methylobacterium radiotolerans VRI8-A4; 7 -Pseudomonas psychrotolerans K-TMV7-6; 8 -Paenibacillus hunanensisCOG-4; 9 - Rhizobium pusense TMV2-6; 10 -Methylobacterium thiocyanatum DSM11490T. 

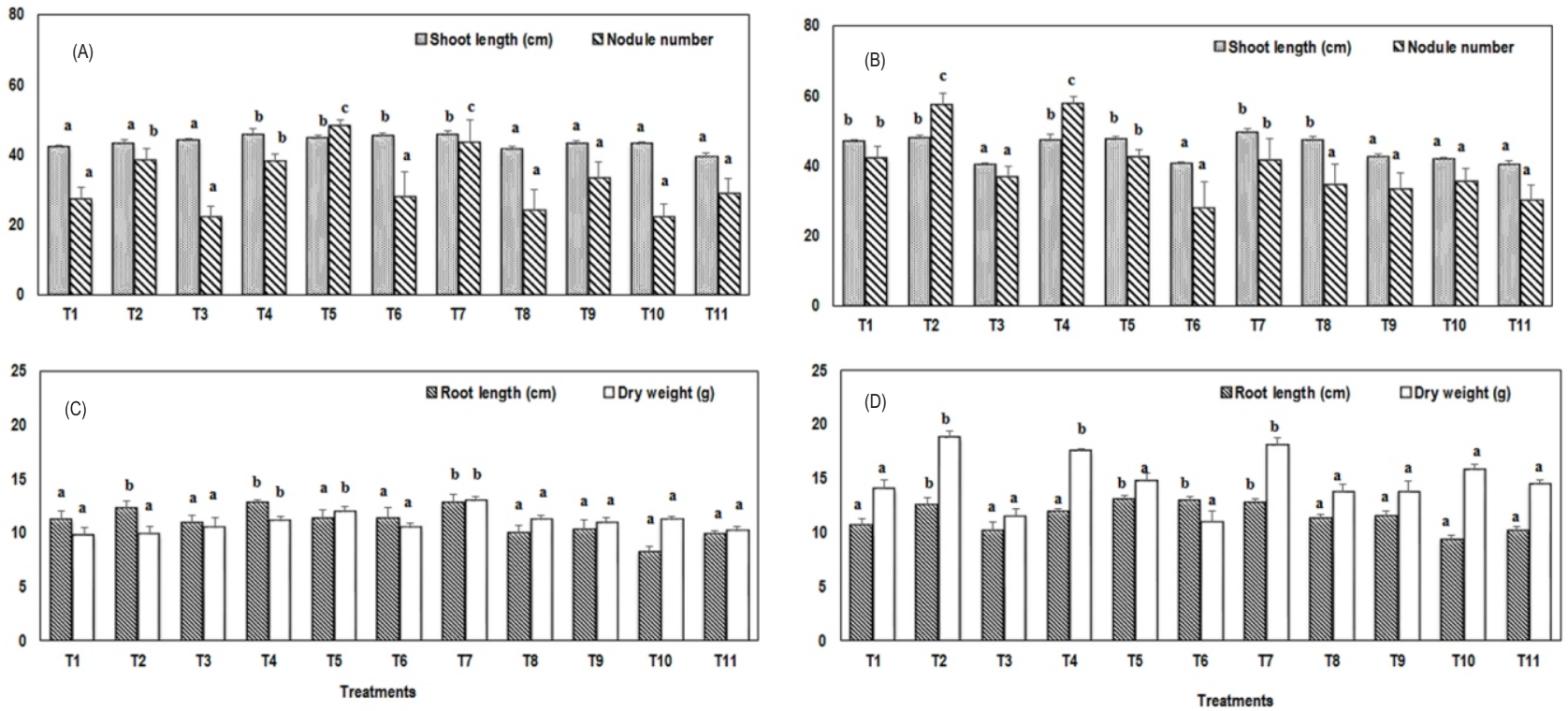

Fig. 2: Effect of methylotrophic bacterial isolates on groundnut growth under field condition after 75 days of sowing at Vriddhachalam (A, C) and Tindivanam (B, D). 1-Acinetobacter baumannii K-TMV7-7; 2-Pantoea stewartii subsp. indologenes N-CO6-5; 3-Pantoea dispersa ICGV-2; 4 -Methylobacterium populi TMV7-4; 5-Methylobacterium thiocyanatum VRI7-A4; 6-Methylobacterium radiotolerans VRI8-A4; 7-Pseudomonas psychrotolerans KTMV7- 6; 8-Paenibacillus hunanensis COG-4; 9 - Rhizobium pusense TMV2-6; 10 - Methylobacterium thiocyanatum DSM11490T. shoot length and nodule number (A, B); Root length and dry weight (C, D) Data are mean of five replicates $\pm S . E ; p<0.05$ according to DMRT, different letters indicate difference among treatments.

In Tindivanam, shoot length and nodule numbers were found to be higher in T2 - Pantoea stewartii subsp. indologenes N-C06-5, T4-Methylobacterium populi TMV7-4, T5 Methylobacterium thiocyanatum VRI7-A4 and T7 Pseudomonas psychrotolerans K-TMV7-6 at 75 DAS (Fig. 2C). Similarly, the dry weight was found to significantly improved by $\mathrm{T} 2$ - Pantoea stewartii subsp. indologenes N-C06-5, T5Methylobacterium thiocyanatum VRI7-A4 and T7 - Pseudomonas psychrotolerans K-TMV7-6 treatments (Fig. 2D). Also Methylobacteirum inoculation significantly increased the biomass accumulation in Jatropha curcas (Madhaiyan et al., 2015).

In Vriddhachalam, the yield of the groundnut was found significantly higher in Methylobacterium thiocyanatum VRI7-A4 followed by Paenibacillus hunanensis COG-4 and Pseudomonas psychrotolerans K-TMV7-6 compared to uninoculated control treatment (Table 2). Previous reports demonstrated the methylotrophic bacteria mediated yield increases (Madhaiyan et al., 2015; Ardanov et al., 2016; de Aquino et al., 2018). A field experiment conducted by Ardanov et al. (2016) showed up to 20 percent yield increase in potato due to the inoculation of Methylobacterium sp. There were no significant variations in kernel oil content among the treatments, however, these parameters were found to be higher in Methylobacterium thiocyanatum VRI7-A4 (51\%). In line with this, Liu et al. (2017) reported that bacterial inoculation not influenced on groundnut kernel oil and protein content at field level experiment. However, inoculation of Rhizobium was found to increase the groundnut oil content compared to the control treatment (Anandham et al., 2007; Hasan and Sahid, 2016). These variations might be caused by many factors such as plant genotype, other biotic and abiotic factors. Crude protein content was found higher in Pantoea dispersa ICGV-2 followed by Methylobacterium thiocyanatum VRI7-A4 followed by Methylobacterium thiocyanatum DSM11490T. Similarly increase in protein content of groundnut kernel was observed in bacteria inoculated treatment compared to uninoculated treatment (Hasan and Sahid, 2016). In Tindivanam, the yield content of the groundnut was found significantly higher in Methylobacterium thiocyanatum VRI7-A4 followed by Pseudomonas psychrotolerans K-TMV7-6 and Methylobacterium populi TMV7-4 compared to uninoculated control treatment. Similarly, Methylobaterium inoculation was found to increase the yield of rice and barely at field level compared to the control treatment (Tani et al., 2015). Yield increased by inoculation of methylotrophic bacteria might be due to the cumulative effect of multiple plant growth promoting traits exhibited by these isolates. There were no significant variations in kernel oil content noted among the treatments in Tindivanam, however, the crude protein content was found higher in Methylobacterium thiocyanatum VRI7-A4 followed by Pantoea dispersa ICGV-2 and Methylobacterium radiotolerans VRI8-A4.

The results of this field studies showed that Methylobacterium populi TMV7-4, Methylobacterium 
thiocyanatum VRI7-A4, Pseudomonas psychrotolerans K-TMV76 inoculants increased groundnut growth and yield compared to control treatment. Hence, these three isolates may be recommended as crop specific bio-inoculant for groundnut after multi-location and on farm trails.

\section{Acknowledgment}

This study was supported by the Science and Engineering Research Board (SERB), Department of Science and Technology (DST) under grant no. PDF/2015/000456.

\section{References}

Akter, S., J. Kadir, A.S. Juraimi and H.M.Saud: In-vitro evaluation of Pseudomonas bacterial isolates from ricephylloplane for biocontrol of Rhizoctonia solani and plant growthpromoting traits. J. Environ. Biol., 37, 597-602 (2016).

Anandham, R., R. Sridar, P. Nalayini, S. Poonguzhali, M. Madhaiyan and T.M. Sa: Potential for plant growth promotion in groundnut (Arachis hypogaea L.) CV. ALR-2 by co-inoculation of sulfur-oxidizing bacteria and Rhizobium. Microbiol. Res., 162, 139-153 (2007).

Alibrandi, P., M. Cardinale, M.M. Rahman, F. Francesco Strati, P. Ciná, M.L. de Viana, E.M. Giamminola, G. Gallo, S. Schnell, C.D. Filippo, M. Ciaccio and A.M. Puglia: The seed endosphere of Anadenanthera colubrina is inhabited by a complex microbiota, including Methylobacterium spp. and Staphylococcus spp. with potential plant-growth promoting activities. Plant Soil, 422, 81-99 (2018).

Ardanov, P., S. Lyastchenko, K. Karppinen, H. Häggman, N. Kozyrovska and A.M. Pirttilä: Effects of Methylobacterium sp. on emergence, yield, and disease prevalence in three cultivars of potato (Solanum tuberosum L.) were associated with the shift in endophytic microbial community. Plant Soil, 405, 299-310 (2016).

Bhardwaj, D., M. W. Ansari, R. K.Sahoo and N. Tuteja: Biofertilizers function as key player in sustainable agriculture by improving soil fertility, plant tolerance and crop productivity. Microb. Cell Fact, 13, 66 (2014). doi:10.1186/1475-2859-13-66

Bradacova, K., A.S. Florea, A. Bar-Tal, D. Minz, U. Yermiyahu, R. Shawahna, J. Kraut-Cohen, A. Zolti, R. Erel, K. Dietel, M. Weinmann, B. Zimmermann, N. Berger, U. Ludewig, G. Neumann and G. Posta: Microbial consortia versus single-strain inoculants: An advantage in PGPM-assisted tomato production. Agronomy., 9, 105 (2019).

Bray, R.H. and L.T. Kurtz: Determination of total organic and available forms of phosphorus in soils. Soil Sci., 59, 39-45(1945).

Bric, J.M., R.M. Bostock and S.E. Silversone: Rapid in situassay for indole acetic acid production by bacteria immobilization on a nitrocellulose membrane. Appl. Environ. Microbiol., 57, 535-538 (1991).

de Aquino, G.S., M.U. Ventura, R.P. Alexandrino, T.A. Michelon, P.G. de Araujo Pescador,T.T. Nicio, V.S. Watanabe,T.G. Diniz, A.L.M. de Oliveira, F.T. Hata, G.S. de Aquino, M.U. Ventura, R.P. Alexandrino, T.A. Michelon, P.G. de Araujo Pescador, T.T. Nicio, V.S. Watanabe, T.G. Diniz, A.L.M. de Oliveira and F.T. Hata: Plantpromoting rhizobacteria Methylobacterium komagatae increases crambe yields, root system and plant height. Ind. Crops Prod., 121, 277-281 (2018).

Devani, M.B., C.J. Shishoo, S.A. Shah and B.N. Suhagia: Microchemical methods: Spectrophotometric methods for micro-determination of nitrogen in kjeldahl digest. J. Assoc. Off. Anal. Chem., 72, 953-956 (1989).
David, K.A.V., S.K. Apte, A. Banerji and J. Thomas: Acetylene reduction assay for nitrogenase activity: Gas chromatographic determination of ethylene per sample in less than one minute. Appl. Environ. Microbiol., 39, 1078-1080 (1980).

Dubois, M., K.A. Gilles, J.K. Hamilton, P.A. Peters and F. Smith: Colorimetric method for determination of sugars and related substances. Anal. Chem., 28, 350-356 (1956).

Hasan, M. and I. Sahid: Evaluation of Rhizobium inoculation in combination with phosphorus and nitrogen fertilization on groundnut growth and yield. J. Agron., 15, 142-146 (2016).

Harish, R., J. Samuel, R. Mishra, N. Chandrasekaran and A. Mukherjee Bio-reduction of $\mathrm{Cr}(\mathrm{VI})$ by exopolysaccharides (EPS) from indigenous bacterial species of Sukinda chromite mine, India. Biodegradation, 23, 487-496(2012).

Hebbar, K.P., B. Gueniot, A. Heyraud, P. Colin-Morel, T. Heulin, J. Balandreau and M. Rinaudo: Characterization of exopolysaccharides produced by rhizobacteria. Appl. Microbiol. Biotechnol., 38, 248-253 (1992).

Hernandez, L.H., J.T. Coutino-Megchun, C.I. Rincon-Molina, V.M. RuizValdiviezo, J.M. Culebro-Ricaldi, R.I. Cruz-Rodriguez, H.H. Palomeque-Dominguez and R. Rincon-Rosales: Endophytic bacteria from root nodules of Ormosia macrocalyx with potential as plant growth promoters and antifungal activity. J. Environ. Biol., 39, 997-1005 (2018).

Itelima, J.U., W.J. Bang, I.A. Onyimba and O.J. Egbere: A review biofertilizer a key player in enhancing soil fertility and crop productivity. J. Microbiol. Biotechnol. Rep., 2, 22-28 (2018).

Jayashree, S., P. Vadivukkarasi, K. Anand, Y. Kato and S. Seshadri: Evaluation of pink-pigmented facultative methylotrophic bacteria for phosphate solubilization. Arch. Microbiol., 193, 543-552 (2011).

Klikno, J. and U. Kutschera: Regulation of root development in Arabidopsis thaliana by phytohormone-secreting epiphytic methylobacteria. Protoplasma, 254, 1867-1877(2017).

Krishna, G., B.K. Singh, E.K. Kim, V.K. Morya and P.W. Ramteke: Progress ingenetic engineering of peanut (Arachis hypogaea L.). A review. Plant Biotechnol. J., 13, 147-162 (2015).

Krishnamoorthy, R., S.W. Kwon, K. Kumutha, M. Senthilkumar, S.Ahmed, T.M. Sa and R. Anandham: Diversity of culturable methylotrophic bacteria in different genotypes of groundnut and their potential for plant growth promotion. 3 Biotech., 8, 275 (2018).

Lau, E., M.C. Fisher, P.A. Steudler and C.M. Cavanaugh: The methanol dehydrogenase gene, $m x a F$, as a functional and phylogenetic marker for proteobacterial methanotrophs in natural environments. PLOS ONE, 8, e56993. (2013).

Liu, D., Q. Yang, K. Ge, X. Hu, G. Qi, B. Du, K. Liu and Y. Ding: Promotion of iron nutrition and growth on peanut by Paenibacillus illinoisensis and Bacillus sp. strains in calcareous soil. Braz. J. Microbiol., 48, 656-670 (2017).

Madhaiyan, M., T.H.H. Alex, S.T. Ngoh, B. Prithiviraj and L. Ji: Leaf-residing methylobacterium species fix nitrogen and promote biomass and seed production in Jatropha curcas. Biotechnol Biofuels., 8, 222 (2015).

Maranz, S., Z Wiesman and N Garti: Phenolic constituents of Shea (Vitellaria paradoxa) kernels. J. Agric. Food Chem., 51, 6268-6273 (2003).

McDonald, I. R. and J. C. Murrell: The methanol dehydrogenase structural gene $m \times a F$ and its use as a functional gene probe for methanotrophs and methylotrophs. Appl. Environ. Microbiol., 63, 3218-3224(1997).

Meena, K.K., M. Kumar, M.G. Kalyuzhnaya, M.S. Yandigeri, D.P. Singh, A.K. Saxena and D.K. Arora: Epiphytic pink-pigmented methylotrophic bacteria enhance germination and seedling growth 
of wheat (Triticum aestivum) by producing phytohormones. Antonie Leeuwenhoek, 101, 777-786(2012).

Mukhongo, R.W., J.B. Tumuhairwe, P. Ebanyat, A.H. AbdelGadir, M. Thuita and C. Masso: Combined application of biofertilizers and inorganic nutrients improves sweet potato yields. Front. Plant Sci., 8, 219(2017).

Pattnaik, S., J. Rajkumari, P. Paramanandham and S. Busi: Indole acetic acid production and growth promoting activity of Methylobacterium extorquens MP1 and Methylobacterium zatmanii MS4 in Tomato. Int. J. Veg. Sci., 23, 321-330 (2017).

Penrose, D.M. and B.R. Glick: Methods for isolating and characterizing ACC deaminase-containing plant growth-promoting rhizobacteria. Physiol. Plant., 118, 10-15 (2003).

Saikia, J., R.K. Sarma, R. Dhandia, A. Yadav, R. Bharali, V.K. Gupta and R. Saikia: Alleviation of drought stress in pulse crops with ACC deaminase producing rhizobacteria isolated from acidic soil of Northeast India. Sci. Rep., 8, 3560 (2018).

Sharma, K.L., Y.S. Ramakrishna, J.S. Samra, K.D. Sharma, U.K. Mandal, B. Venkateswarlu, G.R. Korwar and K. Srinivas: Strategies for improving the productivity of rainfed farms in india with special emphasis on soil quality improvement. J. Crop Impro., 23, 430-450 (2009).

Sharma, S.B., R.Z. Sayyed, M.H. Trivedi and T.A. Gobi: Phosphate solubilizing microbes: sustainable approach for managing phosphorus deficiency in agricultural soils. Springer Plus, 2, 587 (2013).

Subhaswaraj, P., R. Jobina, P. Parasuraman and B. Siddhardha: Plant growth promoting activity of pink pigmented facultative methylotroph-methylobacterium extorquens MM2 on Lycopersicon esculentum L. J. Appl. Biol. Biotechnol., 5, 042-046 (2017).

Tani, A., N. Sahin, Y. Fujitani, A. Kato, K. Sato and K. Kimbara: Methylobacterium species promoting rice and barley growth and interaction specificity revealed with whole-cell matrix-assisted laser desorption / ionization-time-of-flight mass spectrometry (MALDI-TOF/MS) analysis. PLoS ONE, 10, e0129509(2015).

Win, K.T., F. Tanaka,K. Okazaki and Y. Ohwaki: The ACC deaminase expressing endophyte Pseudomonas spp. Enhances $\mathrm{NaCl}$ stress tolerance by reducing stress-related ethylene reduction, resulting in improved growth, photosynthetic performance, and ionic balance in tomato plants. Plant Physiol. Biochem., 127, 599-607 (2018). 